\title{
Policy Interdependence and the Models of Health Care Devolution: "Systems or Federacies"?
}

\author{
Joan Costa-Font and Laurie Perdikis \\ London School of Economics and Political Science (LSE) \\ Contact: Joan Costa Font. Department of Health Policy, London School of \\ Economics. E-mail: I.costa-font@lse.ac.uk
}




\begin{abstract}
A number of European countries have devolved health care services to subnational units. This is especially the case in unitary states that are organised as a national health services (NHS), where choice is not 'build in' the health system and funding is based on general taxation. This policy review paper argues that, in such settings, there are two distinct models of devolving authority to subnational jurisdictions: a 'federacy model' where only a few territories obtain health care responsibilities (such as in the United Kingdom), and a 'systems model' where the whole health system is devolved to a full set of subnational units, (such as in Spain). The choice of one or the other influences the spatial diversity of health care activity and the extent of policy interdependence across regions. We discuss evidence from the UK and Spain to shed some light on the likely effect of each model of devolution. Our results indicate that a 'system model' gives rise to significant policy interdependence and lower regional than a 'federacy model'.
\end{abstract}

Keywords: regional dispersion, models of federalism, federacy, policy interdependence, systems model, spatial diversity, Spain, UK. 


\section{Introduction}

The devolution of public service responsibility in unitary states is a common trend throughout European countries. The OECD (2016) reports that lmost 35\% of public money is spent at the sub-national government level ${ }^{1}$, and it mainly is allocated to fund education, healthcare as well as other key policy areas. Consistntly, a number of European countries have devolved health care services to subnational units (Costa-Font and Greer, 2013). This is a response to a number of different pressures including demands for the expansion of government responsiveness and accountability, efficiency and competition and the enhancement of policy innovation. Such differences give rise to an heterogeneous distribution of authority across the territory. This policy paper examines such heterogeneity in the distribution of health care authority, and how it impacts in some autcomes. More specifically, it will attempt to distinguish between different 'models' of devolution, namely a 'federacy model' and a 'system model'.

We identify a first model of devolution as a 'federacy model', namely one based on the transfer of government responsibilities only to certain specific territories whilst the bulk of the country remain centrally managed. Typically, territories that qualify as 'federacies' can be identified by some distinctive characteristics such as historical rights (e.g., Scotland in the UK or the Basque Country and Catalonia in Spain) or, an implicit demand by the citizenry ${ }^{2}$ among other. However, for the sake of this study it is not important what determined the setup of a federacy, but the effects of adopting a federacy model rather than an alternative one. The alternative model one can devise sits at the other end of the institutional spectrum, and consists in a model

\footnotetext{
${ }^{1}$ Although only $15 \%$ of fiscal revenues tend to be descentralised

${ }^{2}$ This article does not purposefully focus on identifying such historical or distinctive features, but on examining the effects on two relevant policy outcome bearing in mind that both countries examined could have adopted either model of devolution.
} 
where all territorial units are held responsible for a specific policy domain. The latter is irrespectively of the existence of a pre-existing demand for self-governance or historical rights. We define such a model as a 'system of regional governments', or simply, a 'systems model'. In both models health care is publicly funded, and funds allocated to region states in diverse ways. However, most countries employ capitated block grants (e.g., such as the Barnett formula in the UK or an equivalent transfer mechanism in Spain). Similarly, government activity is limited by framework legislation set out at the time of the transfer of government responsibilities. Both models are mutually exclusive, hence, countries that have implemented one model of federalism could well have set up an alternative one. However, whether one model of the other performs better is not trivial, and the purpose of this paper is to contribute to this debate.

Among the main reasons for advocating one model of governance over another, it is claimed, is that of regional 'equality' in the provision of health care. Indeed, in unitary states political pressures tend to develop demands for service uniformity on the grounds of equity. Medical trade unions in the UK have called at times for the centralisation of the working conditions of professionals working for the NHS on the grounds of a hypothetical fragmentation of the NHS, and the need to strengthen the stewardship of the ministry of health. However, the spread of devolution in Spain shows that devolution instead opens up a game of 'follow-the-leader' where regions implementing new reforms (e.g., the Basque Country, Navarra and Catalonia) show the way; the others demand equal treatment, and reforms become widespread in the territory ${ }^{3}$. Hence, it is an empirical question whether keeping health services centralised does indeed manage to reduce the diversity of the health system. This is

\footnotetext{
${ }^{3}$ Other regions such as regional of Madrid only got health care responsibilities in 2002 so could not be a regional leader in the period analyzed. Other regions such as Galicia and Valencia were not pioneers. However, over time, almost every regional did put forward some regional specific, and often-innovative health programs.
} 
especially the case when health care activity and, more generally, the demand for public services is often beyond government control; such as the health care preferences of patients and doctors with regarded to what they value the most form health system benefits. These are at least partly driven by differences and needs (e.g., higher concentration of elderly people might lead to a demand of rehabilitation etc.).

A 'systems model' such as the one we observe in Spain, can give rise to some significant policy interdependence where a number of regions adopt policies that have been already implemented in other regions, and have shown evidence of success. However, in the absence of such policy interdependence one would expect to see diversity in the system. In contrast, 'federacies' are designed to develop 'distinct' health services and hence policy interdependence is not what it seeks to promote, and rarely leads to policy transfer. However, given that a number of regions remain centrally run (e.g. the NHS in England), one would expect to find that uniform policies and regulation would limit diversity, even though that does not necessarily imply outcome uniformity. Whether the dynamics of interdependence are different across governance models, and more specifically, whether they impact in terms of outcome diversity in a different way is a question on which we can garner some evidence.

The UK stands out as a typical example of a 'federacy model' where English regions remain governed by Whitehall, but the three other countries of the UK - Wales, Scotland and N. Ireland - after 2001 were governed from their own territories. In contrast, but at the same time, Spain transferred health care responsibilities to all the Spanish regions or Autonomous Communities (ACs). Originally, health care decentralisation was asymmetric but after 2001 such a more symmetrical system was achieved. Hence, Spain qualifies as a 'systems model'. 
Note that our model distinction is different from the traditional symmetric and asymmetric federalism, as a system model can be asymmetric in its funding (e.g., Basque Country or Navarra in Spain), and a 'federacy model' can be symmetric in its funding (e.g., Barnett's formula in the UK). The difference between the suggested models lies in two different strategies of devolution, one based on dividing the entire territory in governance units (systems model) and the other, in keeping most of the country centralised and only devolving health care to some countries within the UK (federacy model).

This policy note sets out to contribute to the questions of 'what impact does devolution (understood as the regional descentralisation of government activity) have on regional inequality in government activity, and the extent to which the model of devolution makes a difference to this relationship. Specifically, given that both Spain and the UK could have adopted either respective model, we examine whether there are significant differences in terms of regional disparities. To do so, we draw on evidence from the United Kingdom (UK) and Spanish health care devolution. We distinguish the period before and after the onset of the financial crises to examine the potential effect of heterogeneity resulting from spending cuts across the territory. Given that Spain and the UK have a similar health care financing (tax) system, they are reasonably comparable on other grounds. Adding more countries to the analysis would increase the variation on those other features. Health funding in both the UK and Spain is comparable in that both are tax funded and have expended the same proportion of their GDP to health care (see Figure 1). Finally, both are unitary states subject to comparable contexts.

This paper puts forward the claim that there are different models of devolving authority to subnational jurisdictions, and these are consequential. We examine the extent of the impact of the 'devolution model' on two health system outcomes, 
specifically regional disparities and the extent of policy interdependence. Our findings suggest that evidence of the 'system model' of health care devolution examined (Spain) promotes 'homogeneity' and policy explicit interdependence in contract in the UK, even when emulation might take place there is no cognition of the process for political reasons, and diversity is marinating by setting different, and often, non comparable policy goals. We find that regional inequalities exhibit a declining pattern in both Spain and, and the UK. However, the trends in the latter are much weaker.

The remaining of paper is organised as follows. Section two sets out the theoretical background employed in this paper. Section three provides a literature review in context of 'varieties of devolution' and the relationship between devolution and regional inequality. Sections four and five will present this paper's results and discussion.

\section{Background}

\subsection{The Devolution Puzzle}

The process of devolution and its impact upon regional inequality has gained credence within the literature. Some theory suggests that devolution may in fact increase regional inequality because as resources are passed to sub central governments or regions, it consequently weakens inter-regional distribution intended for regional convergence (Prud'homme, 1995). In contrast, some work argues that devolution helps to reduce regional inequality (Oates, 1972; 1993). However, this literature does not distinguish between different models of devolution, and does not specifically examine a homogenous sector of policy activity. Indeed, some public services are more likely to be devolved to sub central governments across countries than others. Health care is the most common public 
service responsibility that has been devolved among European Union member states, and hence it has been compared across countries. The focus on one public service (health care) is important as health care is comparable across the two countries under examination in both how it is funded and the principles it is grounded. However, in what follow we not attempt to describe the institutional differences and historical legacies between Spain and the UK, but the observed regularities in policy outcomes after devolution was implemented bearing in mind that health care was centrally managed before devolution was implemented, and that both countries could have adopted either model of devolution described (e.g., Spain could have devolved health care only to Catalonia, Basque Country and Galicia, or the UK could have devolved health care to all English regions too).

Whilst the devolution process in the UK was indeed accelerated under the 'New' Labour government, a centre-left party, of 1997-2010, the current Conservative government of 2015, has also taken a 'pro-devolution' stance and it too has begun to speed up the process ${ }^{4}$. The second caveat proffered by Costa-Font $(2010 \mathrm{a}, \mathrm{b})$ concerns innovation in welfare systems. He argues that experimentation can lead to enhancements in welfare at the regional levels and support of this, Costa-Font and Rico (2006a) found that, more prominently, innovation in one region can spread to others and thus create a 'race to the top' as opposed to the argument of a 'race to the bottom'. Moreover, in a further study Costa-Font and Rico (2006b) argue that if successful policies are copied by neighbouring and other regions i.e. via lesson drawings, regional inequality would decrease and not increase. They conclude that devolution actually decreases regional inequality (see also McEwen, 2005; Shaw et al. 2009).

\footnotetext{
${ }^{4}$ As can be seen in the example of the devolution of healthcare spending to Manchester. Moreover, in the Chancellor George Osbourne's budget in July 2015, he also put forward the devolution of expenditure to Cornwall and set out on a so called 'devolution revolution'.
} 
The explanation of policy diffusion and divergence for the reduction in inequalities and the reasons behind different politico-economic systems has been put forward by various scholars. MacKinnon (2015) who argues that devolution has had a significant impact upon public policy both in Wales and Scotland. Another long term impact put forward in the literature is the political influence upon policy which has produced divergence for example in Wales and Scotland, less market-orientated reforms, with more social democratic approaches to policy (Mackinnon, 2015; Greer 2003; Birrell, 2010). Indeed, given that latter governance models (localism and public health in Wales vs. professionalism and cooperation in Scotland) are chosen policy options, they were intended models of governance which could have been adopted by other countries in the UK.

The models of governance within the UK are not absent of comparison, emulation or policy learning, although the strategy was instead not to acknowledge comparative improvements in other countries and set diverging policy goals instead. For example, there is little doubt that longer waiting times in Wales compared with England spurred the Welsh Assembly government to give waiting time reduction greater priority. Scotland similarly took waiting times more seriously when its government saw performance in England. However, there was no explicit recognition of the process for obvious political reasons, and instead they focusing diverging policy goals to avoind being compared.

Undoubtedly, it is these political games per se that have a bearing upon policy and thus, make up the types of devolution seen in Spain and the UK. Therefore, within a federacy the politics of difference is a central characteristic.

\section{Models of Devolution: The UK and Spain}


Both the UK and Spain embarked on their process of devolution for similar reasons, and can be defined as unitary states that share some aspects of federal states ('quasifederal states'). Both the UK and Spain differ significantly in terms of the transfer of powers to their regional governments. Therefore, we can argue that both the UK and Spain exhibit different 'varieties of devolution' and that devolution is indeed highly variegated in these two examples (Peck and Theodore, 2007). Devolution in the UK is based upon the separation of political and fiscal powers between the devolved parliaments of Scotland, Wales and N. Ireland, and the UK parliament (Keating, 2002; Mackinnon, 2015). Therefore, some leeway is given to these devolved governments in the development of their own particular policies. Nevertheless, the UK Parliament, can still legislate under law, in theory and in practice, for Scotland, Wales and N. Ireland.

In the UK, the three devolved administrations receive a block allocation from the UK Parliament in Westminster out of which they have to decide what proportion should be allocated to the NHS, social care, education and so on. This compared the Spanish case where block grants are received form the Spanish government except for the Basque Countty and Navarra who are fully fiscally accountable. However, it is important to point out that the Barnett formula that determines these block allocations predates political devolution.

An important difference between the UK and Spain lies in that post-devolution UK lacks any UK-wide, federal governance institutions. For example, there is no federal ministry of health. However, this is not the case in Spain where the Minisitry of Health does exist and exerts some important coordinantion roles alongside the provision of information. The only exception where the UK and Spain compared is the fact that the English Department of Health undertakes some UK-wide roles on 
behalf of the other three devolved administrations in relation to international relations affecting the NHS.

The Government of Wales Act 1998 was the impetus for devolution in Wales, creating the Welsh Assembly and devolving powers in areas such as healthcare provision. The Scotland Act 1998 in contrast, granted powers to the Scottish Parliament on a reserved basis whilst in Northern Ireland, the Good Friday Agreement 1998 paved the way for the devolution of powers under the Northern Ireland Act 1998. It is also important to note that the devolved parliaments have narrow revenue-raising powers (MacKinnon, 2015). Importantly, and similalrly to the Spanish case, the devolved assemblies and Scottish Parliament in the UK are elected on a quite different basis from the Westminster Parliament, using variant forms of proportional representation and that this may well affect the nature of the policies adopted in the devolved administrations. Hence, the political majorities in the develoved assemblies do not necessarily reproduce the elelctoral results of nation-wide elelctions.

As of 2014, Wales has received some limited tax raising powers in the form of stamp duty and landfill tax. Absent from devolution is England, which has one government and legislature, namely the UK Government and UK parliament respectively, compared to two each for Scotland, Wales and N. Ireland. The UK, therefore, can be best described as a state categorised by the 'federacy model' (Rokan and Unwin, 1983; Rhodes, 1997; Keating, 1998; Cooke and Clifton, 2005). In contrast to the UK, Spain has a different devolutionary arrangement. Paradoxically, Spain began as a highly centralised, unitary state which has undertaken asymmetric devolution, passing power to the 17 'autonomous communities', (Carbonell and Alcalde, 2008; Maiz et al. 2008). However, Spanish devolution has evolved a 'systems model', especially in the area of health care. Since 2002, all ACs have had 
the same responsibilities except for two; the Basque Country and Navarra, which collect their own taxes and are thus, fiscally independent and politically accountable for running healthcare provision (Prieto and Lago-Penas, 2012).

The concept of 'varieties of devolution' is directly applicable to healthcare because unlike the UK where healthcare is devolved to Scotland, Wales and N. Ireland, although not yet to England and its regions (apart from Manchester as of 2015), Spanish healthcare management is devolved to its $17 \mathrm{ACs}$.

The size of the devolved administration are consistent with the federacy in the UK $\mathrm{v}$ system model of devolution in Spain. Although the total population of the UK is larger overall than Spain, the UK model has kept until 2014 an English NHS that provides care to 53 million individuals centralised, whilst the population of the devolved adminsitartions amount only to one fith of of such figure ( Scotland 5.2 million, 3 million and Notern Ireland 1.8 million). In contrast in Spain, the 47 million inhabitants receive descentralised health care and regional populationsize ranges from 8 million in Andalucia, 7.5 million in Catalonia to 0.3 million in La Rioja.

Finally, it has been argued that the UK is characterised by four healthcare models. Wales adopted a system based on localism, a bottom up approach to healthcare. In comparison, Scotland exhibits a model of medical professionalism, Northern Ireland a model of permissive managerialism; whilst the English model, unsurprisingly, is focused on a market and performance management approach (Greer, 2004). The notion of the 'politics of difference' is a central characteristic in the type of devolution associated with the UK, and is directly reflected in the approach to healthcare. This approach can be attributed to the permissive nature of the type of devolution, which 
facilitates policy divergence (Mackinnon, 2015; Greer, 2007, Jeffery, 2007). Spain, in contrast with its devolved healthcare systems and independent fiscal regions, is more akin to the 'systems' model of devolution.

\section{Regional Diversity}

To examine the effects of devolution on convergence, a simple and commonly accepted strategy is to identify a measure of health care output (unadjusted health expenditure per capita) and examine an inequality index. Consistently with previous studies we employ the coefficient of variation as its simple to interpret and its comparable as in a number of previous studies (Costa-Font, 2010a, Costa-Gont and Turati, 2017). Figure 2, provides the evidence of the trends in unadjusted per capita health expenditure in Spain, England and the UK as a whole. Measure of coefficient of variation are based at the regional level, in the UK it follows the estimates of the Office of National Statistics which defined the 9 regional in England. Hence, overall the coefficients of variations are comparable for Spain and the UK. However, we limit the analysis between 2000-2009 to avoid the results being confounded with the effect of the economic downturn. Figure 1, suggests a reduction in the coefficient of variation of unadjusted public expenditure per capitals over the period 2000-2009, highlighting a downward trend in terms of regional disparities. For example, decreasing from 0.006 to 0.004 in the same period. In contrast, there is more of a discrepancy when analysing the UK as a whole, which has seen a more turbulent movement in the level of regional disparities, which is significantly larger when we examine England than the UK as a whole. As such, in the short term, it can be argued that in the cases of both Spain and the UK, both show a decrease in regional inequality which happens to be speeder in the Spanish 'system model'. Similar results are found when Italy is included in the analyssys as suggested by Costa-Font 
and Turati (2017). This results is consistent wuth our argument as Italy qualifies as a system model along the lines of Spain.

\section{Policy discussion}

This policy note has discussed the effect of the Spanish and British model of federalism on regional diversity and policy interdependence. Overall, we find that that devolution has not increase regional inequalities, but in a systems model and in Spain we find a stark reduction of regional diversity and larger policy interdependence which is not observed in the Bristish model of devolution. This also consistent with Costa-Font (2010) who finds a reduction in regional inequalities in welfare activity in Spain, with devolution playing a significant role. Consistently with Pollock (1999) and Morgan (2002), we find that devolution has helped to address regional preferences in healthcare. Devolution has allow the NHS in Wales, Scotland and Northern Ireland to be tailored to its preferences (e.g., elimination of prescription charges, free long term care in Scotland) overcoming the potential veto in a centralized UK-wide health system.

Although we find that diversity in health care activity is higher in the UK than in Spain, this could be be explained by different political legacies and dynamics in additionl to the model of devolution However, these have not been radically modified over the period observed, and hence they are unlikely to explain the changing patterns of regional health inequality. Instead, explanations for the reduction of regional health care idiversity in Spain can be explained by the existence of policy interdpedencence, where regions learned for each other and expand services that show successful results. For example, there has been significant diffusion in health and ageing services in Catalonia, the right of a second media opinion in the Cananry Islands and the expansion of dental health care converage 
for children in the Basque Country (Costa-Font and Rico, 2006). In contrast, the UK devolution was tailored to expand diversity. As Andrews and Martin (2010, p.929) note 'the creation of new devolved political institutions in 1999 placed the pursuit of distinctive policy agendas on a far firmer constitutional footing... unleashing much more forceful and explicit expressions of the ideological and cultural differences between different parts of Britain'. The pursuit of policy divergence therefore plays a key role in debates such as the relationship between regional inequality in healthcare provision and devolution. However, the UK could lean towards a sustem model if further devolution was to take place in Engalnd. Should health policy be devolved to England as a whole -and that level of government made distinct from the UK level, a centre region dynamic might emerge. Needless to say, one needs to acknowledge some level of policy comparison over health policy does exist in the UK, for example as between Wales and England does exist when it comes to the adoption of some policies like ambulance time target in England (Bevan, 2014). However, so far it has not produce major policy changes in the policy priorities of each countries. Finally, it is worth acknowledging that both models of devolution show no expansion of regional inequalities after devolution, and therefore the myth surrounding classical arguments against devolution on the basis of increased inequality should be dispelled.

\section{Conclusions}

This policy review paper compared two models of devolution implemented in Spain and the UK on policy diversity and interdependence. As expected our evidence suggests different trends on inequality in healthcare expenditure per capita and policy interdependencein Spain and the UK after devoliution. In the Spanish NHS we find large policy interdependence and stark reduction of regional inequalities, whilst in the UK we find an expansion of policy divergence, and hardly no change in 
regional inequality patterns. Hence, these results shed light on a central feature of the devolution debate, namely that reducing central level government role in health policy making does not encompass the expansion of of regional inequalities, and can leads to spontaneous policy interdependence. However, for obvious reasons the results do not establish a causal association. They are consistent with similar studies comparing devolution in Italy and Spain, which suggest that in both countries devolution did not increase regional inequalities (Costa-Font and Turati, 2017). However, it is important to bear in mind that these predictions do not automatically hold on in other health systems where health care is not publicly funded.

This policy paper makes a contribution to the policy debate surrounding the potential impact of devolution on regional inequalities. As of February 2015, the UK government devolved control of National Health Service (NHS) spending to the Greater Manchester region. Budget responsibility will be devolved to a partnership of councils and local NHS commissioning groups and providers. Our results would suggest if devolution is extended to other English regions it has the potential to reduce regional inequality in healthcare. A policy that has hitherto not been adopted so far. Hence, there is a chance that existing regional diversity in the Bristish NHS could be corrected by further devolution of health care repsonsabilities ot regional authorities.

\section{References}

Andrews, R and Martin, S. (2010). Regional Variations in Public Service Outcomes: The Impact of Policy Divergence in England, Scotland and Wales. Regional Studies. 44 (8), p. 919-934. 
BBC News. (2015). Election 2015: A short guide to devolution in the UK. Available: http: / / www.bbc.co.uk/ news/ election-2015-31502626. Last accessed 27th March 2015.

Bevan, G, Karanikolos, M, Exley, J, Nolte, E, Connolly, S and Mays, N. (2014). The four health systems of the United Kingdom: how do they compare? Available:

http: / / www.nuffieldtrust.org.uk/sites / files/nuffield/revised_4_countries_report.p df. Last accessed 20th March 2015.

Costa-Font, Joan and Turati, Gilberto (2017) Regional health care decentralization in unitary states: equal spending, equal satisfaction? Regional Studies

Costa-Font, J and Greer, S. L. (2013). Territory and Health: Perspectives from Economics and Politcal Science. In: Costa-Font, J and Greer, S. L Federalism and Decentralisation in European Health and Social Care. Basingstoke: Palgrave Macmillan. p. 13-35.

Costa-Font, J and Rico, A. (2006a). Vertical competition in the Spanish National Health System (NHS). Public Choice. 128, p. 477-498.

Costa-Font, J and Rico, A. (2006b). Devolution and the Interregional Inequalities in Health and Healthcare in Spain. Regional Studies. 40 (8), p. 875-887.

Costa-Font, J. (2010a). Does devolution lead to regional inequalities in welfare activity? Environment and Planning C: Government and Policy. 28, p. 435-449.

Costa-Font, J. (2010b). Devolution, Diversity and Welfare Reform: Long-term Care in the 'Latin Rim'. Social Policy and Administration. 44 (4), p. 481-494. .

Greer, S. L. (2003). Policy divergence: will it change something in Greenock. In: Hazell, R The State of Nations 2003: The Third Year of Devolution in the United Kingdom. Exeter: Imprint Academic. p. 195-214.

Greer, S. L. (2004). Four Way Bet: How devolution has led to four different models for the NHS: The Constitution Unit. Available:

https: / / www.ucl.ac.uk/spp/publications / unit-publications/106.pdf. Last accessed 20th July 2015.

Greer, S. L. (2007). The Fragile Divergence Machine: Citizenship, Policy Divergence and Devolution. In: Trench, A. Devolution and Power in the United Kingdom. Manchester: Manchester University Press.

Hewitt, G. (2012). Spain budget: Cuts to total $27 b n$ euros this year. Available: http: / / www.bbc.co.uk/ news/ business-17557172. Last accessed 22nd July 2015.

Keating, M. (1998). What's wrong with asymmetrical government? In: Elcock, H and Keating, M Remaking the Union. Devolution and British Politics in the 1990s. London: Frank Cass. p. 203-222.

Keating, M. (2002). Devolution and public policy in the United Kingdom: divergence or convergence? In: Adams, J and Robinson, P Devolution in practice: public policy differences within the UK. London: Institute for Public Policy Research (IPPR) and the Economic and Social Research Council (ESRC). p. 3-21. 
Keen, M and Marchand, M. (1997). Fiscal competition and the pattern of public spending. Journal of Public Economics. 66, p. 33-53.

Kingston, S. (2012). The European Court of Justice and the Devolution of Taxation Powers. In: Cloots, E, De Baere, G and Sottiaux, S Federalism in the European Union. Oxford: Hart Publishing Ltd. p. 249-263.

Kneebone, R. D. (1992). Centralisation and size of government in Canada. Applied Economics. 24, p. 1293-1300.

Litchfield, L. (1999). Inequality: Methods and Tools. World Bank. Available: http:/ / siteresources.worldbank.org/INTPGI/Resources/Inequality/litchfie.pdf. Last accessed 4th July 2015.

Litvak, J, Ahmad, J and Bird, R (1998). Rethinking Decentralisation in Developing Countries. Washington DC, Sector Studies; the World Bank.

Lovering, J. (1999). Theory led by policy: the inadequacies of the 'new regionalism'. Journal of Urban and Regional Research. 23. p. 379-395.

MacKinnon, D. (2015). Devolution, state restructuring and policy divergence in the UK. The Geographical Journal. 181 (1), p. 47-56.

McEwen, N. (2013). Independence and the Territorial Politics of Welfare. The David Hume Institute Research Paper. 4 (2013), Edinburgh.

McEwen,N. (2005). The Territorial Politics of Social Development in Multi-level States. Regional and Federal Studies. 15. p. 537-54.

McKinnon, R (1997) Market-preserving fiscal federalism in the American monetary union. In: Blejer M, and Ter-Minassian, $\mathrm{T}$ (eds) Macroeconomic dimensions of public finance: Essays in honour of Vito Tanzi. Routledge, London.

Moreno, L. (2007), Federalization in Multinational Spa, in M. Burgess and J. Pinder (eds), Multinational Federations. London: Routledge, p.142-189.

Morgan, K. (2002). The English question: regional perspectives on a fractured nation. Regional Studies. 36, p. 797-810.

Morgan, K. (2006). Devolution and Development: Territorial Justice and the NorthSouth Divide. Publius: Journal of Federal Studies. 36 (1), p. 189-206.

Murphy, P and Caborn, R. (1996). Regional government: An economic imperative. In: Tindale, S, the State and the Nations. London: Institute for Public Policy Research (IPPR). p. 182-221.

Oates, W (1972). The Political Economy of Federalism. Lexington: Lexington Books, MA.

Oates, W. (1994). Fiscal decentralisation and economic development. WP 04, Department of Economics. University of Maryland, College Park, MD.

Oates, W. (1997). On the welfare gains from fiscal decentralisation. Journal of Public Finance and Public Choice. 15, p. 83-92.

Oates, W. (1999). An essay on fiscal federalism. Journal of Economic Literature. 36, p. 1120-1149. 
Obinger, H, Leibfried, S and Castles, F G, (2005). Federalism and the Welfare State: New World and European Experiences. Cambridge: Cambridge University Press.

OECD (2016). Fiscal Federalism 2016: Making Decentralisation Work. OECD Publishing.

Peck, J (2010). Constructions of neoliberal reason. Oxford: Oxford University Press.

Peck, J and Theodore, N. (2007). Variegated Capitalism. Progress in Human Geography. 31 (6), p. 731-772.

Peck, J and Tickell, A. (2002). Neoliberalising space. Antipode. 34, p. 380-404.

Pierson, P (1994). Dismantling the welfare state? Cambridge: Cambridge University Press.

Pollock, A. (1999). Devolution and health: challenges for Scotland and Wales. British Medical Journal. 318. p. 1195-1198.

Prieto, D.C and Lago-Penas, S. (2012). Decomposing the determinants of health care expenditure: the case of Spain. The European Journal of Health Economics. 13, p. 19-27.

Prud'homme, R. (1995). On the dangers of decentralization. World Bank Research

Observer. 10, p. 201-220.

Redwood, J (1999). The Death of Britain. Basingstoke: Macmillan.

Rhodes, R (1997). Understanding Governance. Buckingham: Open University Press.

Rico, A and Costa-Font, J. (2005). Power rather than path? The dynamics of institutional change under health care federalism. Journal of Health Politics, Policy and Law. 30 (1), p. 231-252.

Rokkan, S and Urwin, D (1983). Economy, Territory, Identity: Politics of Western European Peripheries. London: Sage.

Shaw, J, MacKinnon, D and Docherty, I. (2009). Divergence or convergence? Devolution and transport policy in the United Kingdom. Environment and Planning C: Government and Policy. 27. p. 546-567.

Watts, R. L. (2008). Comparing Federal Systems. 3rd ed. Kingston: McGill-Queen's University Press. 


\section{Figures}

Figure 1. Relative Expenditure (\%GDP)

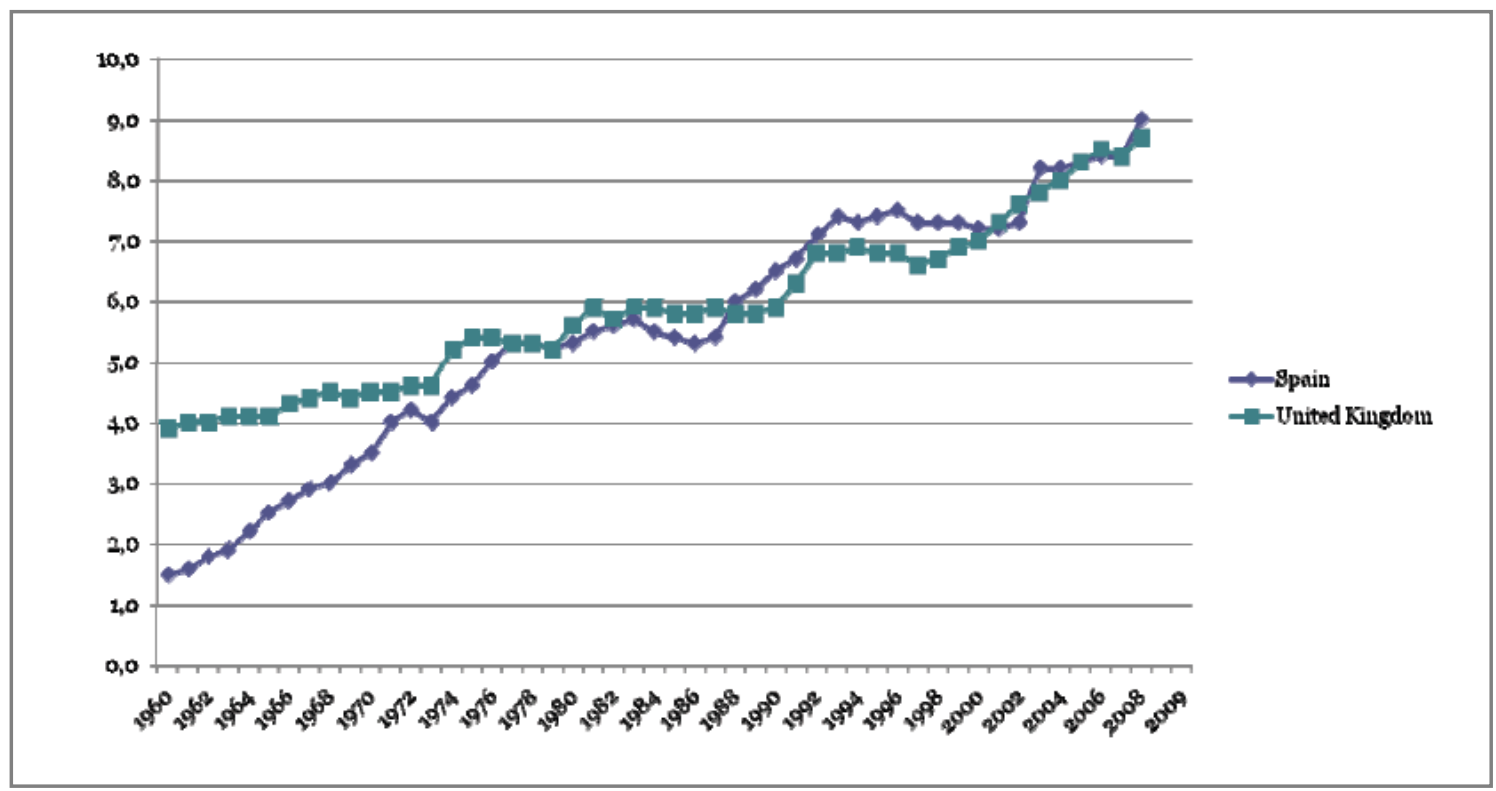

Source: OECD, 2012.

Figure 2. Regional Inequalities on Unadjusted Health Care Output (expenditure

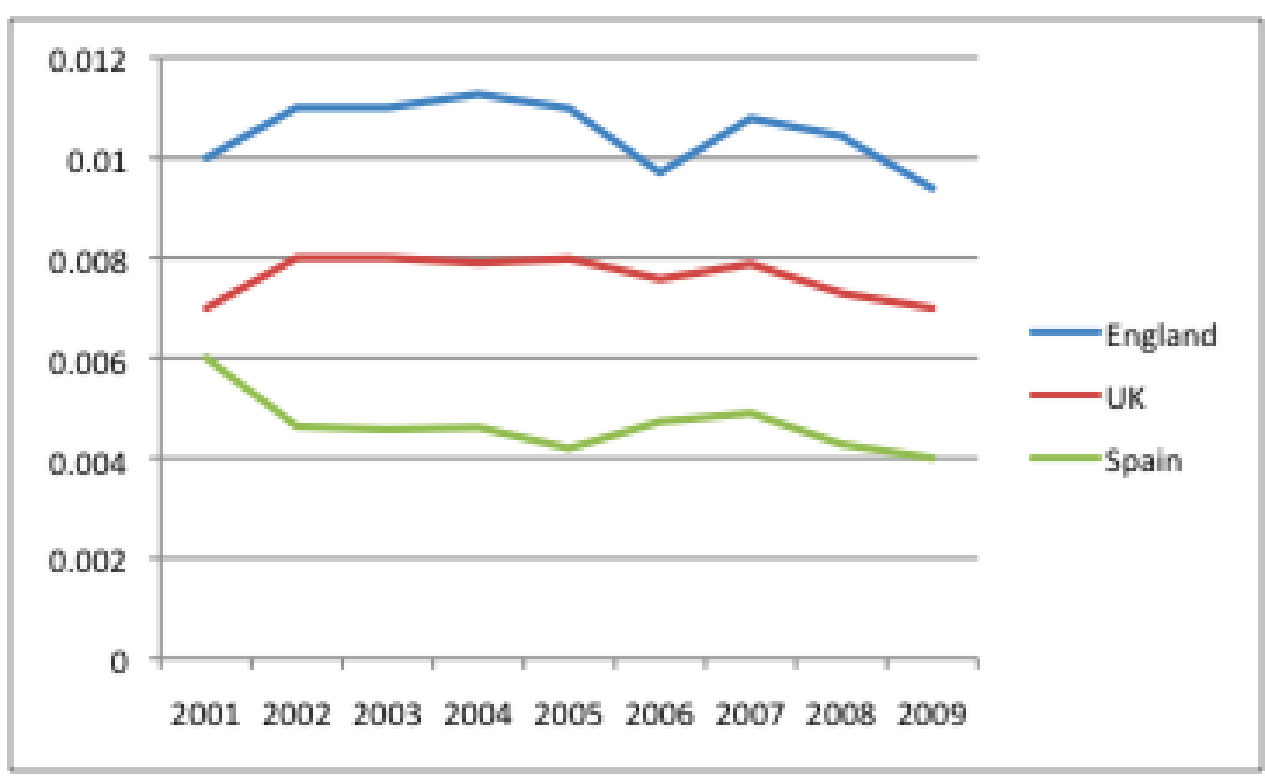

per capita) 
Source: MT Treasury and Spanish Ministry of Health, 20012. Note: Inequalities are measures as the coefficient of variation of the unadjusted per capita health care spending in each of the units examined. The coefficient of variation is defined as the ration between the standard deviation and the mean of the variable. 